\title{
Edinburgh in 2004
}

The 8th Congress of the European Society of Contraception is being held at the Edinburgh International Conference Centre in Edinburgh, UK on 23-26 June 2004. Edinburgh has a dynamic and innovative family planning and reproductive health service, as well as being a thriving, cosmopolitan city that is well worth visiting. The conference centre is located in the heart of the city, just a short walk from art galleries, museums, shops and parks.

Over the centuries, Edinburgh has been at the forefront of many major developments in reproductive health with original contributors whose influence has spread far beyond the capital city. Sir James Young Simpson, the Edinburgh Professor of Midwifery and Diseases of Women, is best remembered for his introduction in 1847 of chloroform for obstetric anaesthesia and analgesia. Although his great discovery was largely ignored at the time because of the prejudice and ignorance of his colleagues, it became widely available once Queen Victoria herself used chloroform for the birth of Prince Leopold 6 years later. In Simpson's later professional years, the average family size in Scotland was 6.9: over 600 women annually died in childbirth and more than 14000 babies born did not survive the first year of life. Contraception was considered 'too impolite to speak about openly' and most doctors in Scotland at that time were firm upholders of traditional Calvinist morality.

The family planning pioneer, Marie Stopes, was born in Edinburgh in 1880 'following chloroform anaesthesia at the last' and attended St George's School for Girls as a young pupil (Figure 1). Married Love,${ }^{1}$ her book on marital relationships and birth control, was an immediate bestseller in the UK although banned in the USA where it was

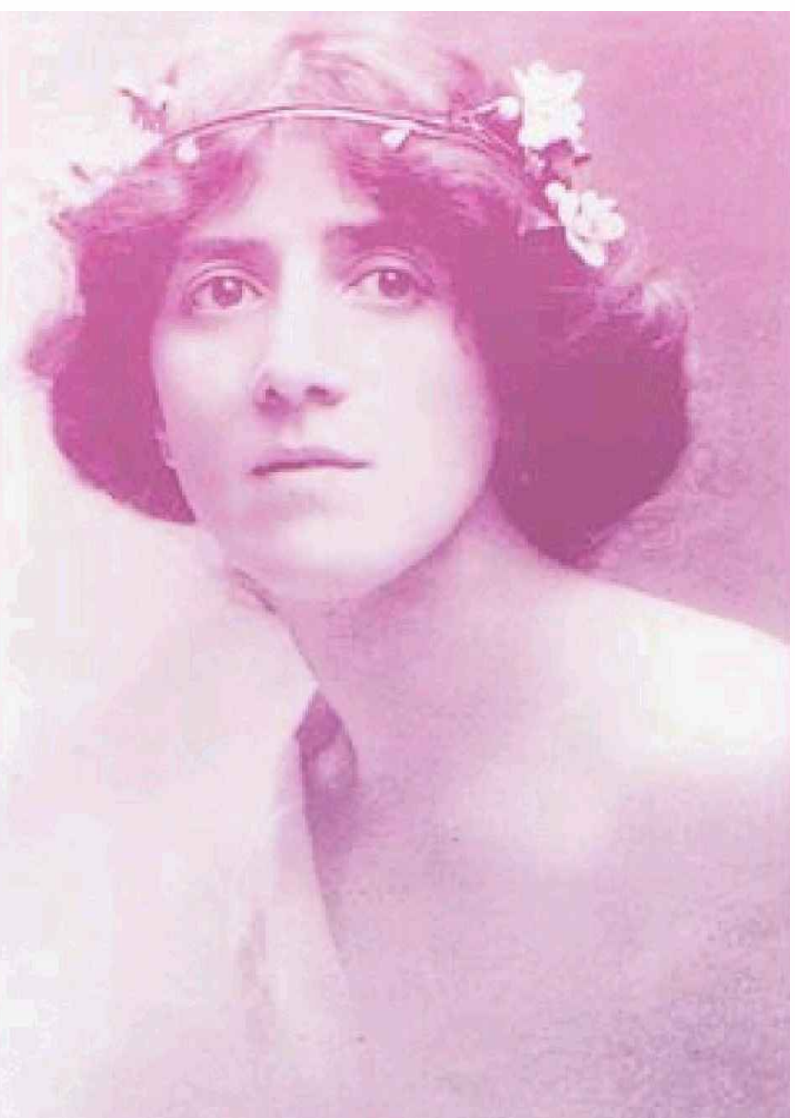

Figure 1 Marie Stopes (photograph courtesy of Gazetteer for Scotland)

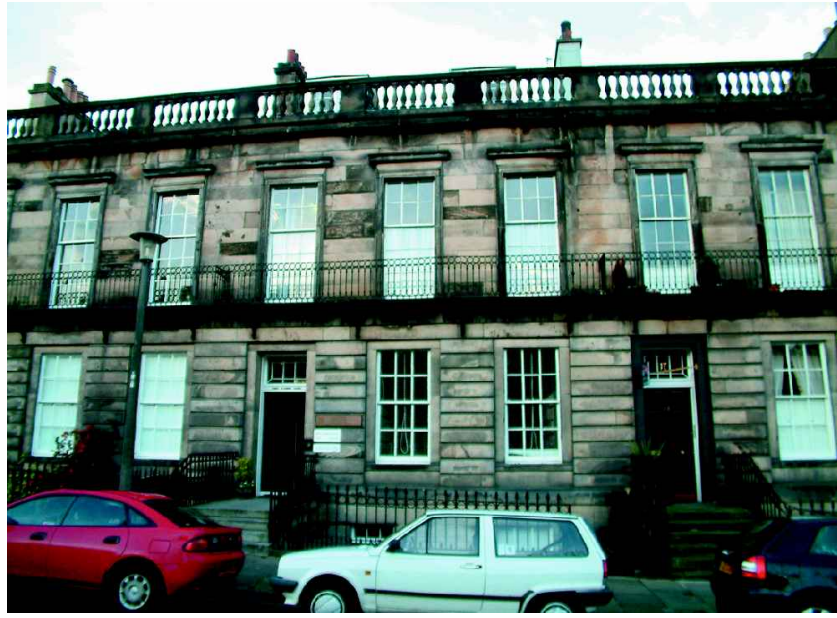

Figure 2 Offices of the Family Planning Service in Dean Terrace, Edinburgh, UK (photograph courtesy of Richard Loudon)

branded obscene. Marie Stopes established the British Empire's first family planning clinic (FPC) in 1921 although apparently she remained opposed to 'chemical methods' of contraception.

The fictional Miss Jean Brodie ${ }^{2}$ was in her prime in Edinburgh and channelled her energies into educating 'her girls' on the nature of love and the ways of men, courtesy of Muriel Spark who attended James Gillespie's High School for Girls.

The first FPC was opened in Edinburgh in 1933 as the euphemistically named 'Edinburgh Mothers' Welfare Clinic' with money raised by the sculptor Hazel Armour and her friends. Through marriage, Hazel Armour was associated with Jenners, the distinguished family-owned department store on Princes Street that is still an Edinburgh institution. The Edinburgh Mothers' Welfare Clinic was a charitable institution that charged women one shilling, together with a fee for appliances to those who could afford it, but both charges were waived in necessitous cases. Eyebrows were raised when a separate premarital clinic was quietly established in 1954 and young women had initially to produce their banns of marriage as proof of their true intent. With the advent of new contraceptive methods in the late 1950s, the service expanded greatly and such was the demand that women requesting oral contraception consulted in small groups in the early 1960s. Various premises were occupied around Edinburgh until, in 1956, a generous bequest allowed the purchase of the building at 18 Dean Terrace which still serves as the centre of today's Family Planning Service (Figure 2). The building was selected for its location in a quiet residential area, which was not overlooked, just a few minutes' walk from the city centre. For many years the clinic services were run by a devoted band of women who gave their services voluntarily but by 1950 both doctors and nurses were remunerated with a small fee.

In 1955, another family planning pioneer, Dr Nancy Loudon, began working within the FPC in Edinburgh and went on to become the medical co-ordinator of the greatly expanded service until 1988. She undertook many of the earliest pill studies, established vasectomy and colposcopy services, and later developed a centralised service for abortion referral in Lothian that allowed general practitioners (GPs) to telephone Dean Terrace to obtain the first available hospital appointment for a woman. Family 
planning was incorporated into the undergraduate curriculum and GPs undertook training in family planning. Nancy Loudon was the first to suggest 'tricycling' of pill packets and promoted a Day 1 start for new pill users. ${ }^{3} \mathrm{~A}$ tricyclic preparation of the pill has just been marketed in the USA, and is rumoured to have given a pay-off of one million dollars for the scientist who patented it there! Following Dr Loudon's retirement, Dr Anna Glasier was appointed as Consultant and Director of Family Planning Services. She has continued the trend of academic interest in contraception with distinguished work, particularly on emergency contraception. Through her work, the Dean Terrace Centre has established links with the World Health Organization, the Population Council and the International Planned Parenthood Federation. The Handbook of Family Planning and Reproductive Healthcare 4 edited in Edinburgh is one of the UK's family planning 'bibles'.

Under the guidance of Professor Roger Short, a veterinary surgeon, of the Medical Research Council (MRC) and Professor David Baird of the University Department of Obstetrics and Gynaecology, the Centre for Reproductive Biology was established in Edinburgh in the 1970 s to allow a close interaction between academic clinicians and scientists. David Baird went on to make enormous contributions in the field of reproductive medicine with research on endocrinology, infertility and, in particular, new methods of abortion. He and Anna Glasier set up the MRC-funded Contraceptive Development Network which co-ordinates contraceptive research centres in Shanghai, Cape Town, Hong Kong and Sagamu, Nigeria. Another notable personality involved with the Family Planning Service in Edinburgh was the psychiatrist, Dr John Bancroft, whose interests in human sexuality extended to premenstrual syndrome and the menopause before he moved on to become director of the notable Kinsey Institute in Bloomington, IN, USA. The leadership of Edinburgh breast surgeon, Professor Sir Patrick Forrest, established the foundations of the UK mammographic breast screening service as encapsulated in the Forrest Report. ${ }^{5}$ Edinburgh also has one gynaecologist, now retired, who did his own vasectomy!

The Family Planning Centre in Edinburgh remains within cramped conditions in a Georgian town house. No space is unfilled and research fellows can be found beavering away in broom cupboards. For the last 5 years, The Wellcome Trust has sponsored an MSc in Reproductive Health, which allows doctors from developing countries to spend a year in Edinburgh to obtain this postgraduate qualification before returning to their own countries to set up research centres in reproductive health. Students from all corners of the globe have participated in this programme and enhanced the crosscultural environment of the FPC. The Edinburgh Menopause Clinic is based here and has been the guiding centre for local GPs on the highs and lows of hormone replacement therapy since 1989 .

The necessity for a new family planning building is imperative. However, Edinburgh's flagship hospital, the New Royal Infirmary of Edinburgh, was built recently as a private finance initiative and there are real concerns that the legacy of the cost of that project and ongoing burden of debt will stifle any new developments within the city.

Edinburgh continues to flourish as a city with a vibrant heart. It has shed its image as the Trainspotting HIV capital of the north and enjoys its current image as a financial and legal powerhouse with many companies relocating here for a better quality of life. The city centre remains a prime residential area with house prices not far off the London scale. During the summer, Edinburgh becomes alive with its internationally renowned Festival plus the alternative

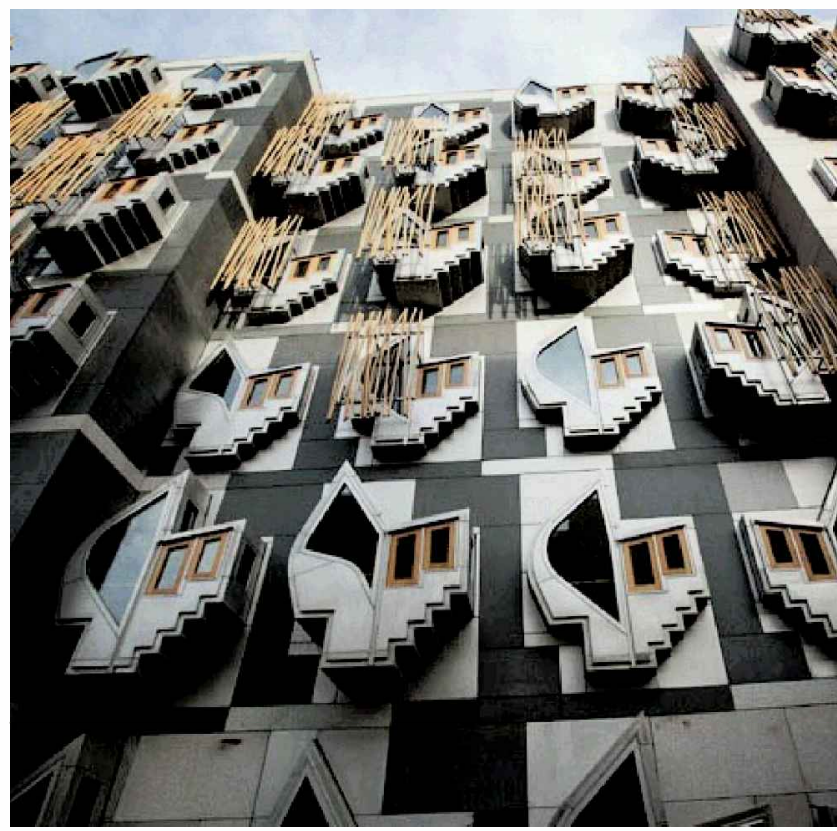

Figure 3 Western aspect of the new Scottish Parliament (photograph courtesy of the Scottish Parliament)

'Fringe', film, jazz and television festivals. The long summer days with pavement cafes and street performers now give the city an unaccustomed, continental feel. The Edinburgh weather even seems to have mellowed in recent years. Edinburgh's newest retail recruit, Harvey Nichols, now rivals Jenners, the old, established, family-owned store. Rumours are rife that the Edinburgh population is proving too tight-fisted to pay up for the luxury lifestyle of Harvey Nichols and that the store may relocate across to Edinburgh's more fashion-conscious rival, Glasgow. The Scottish Parliament building at Holyrood designed by the late Catalonian architect, Enric Miralles, has become an item for national debate as costs have escalated almost tenfold. The building has taken its cues from upturned boats on the Scottish coastline and the delicate floral paintings of Charles Rennie Mackintosh with a distinctly Antoni Gaudi influence (Figure 3).

Reproductive health is alive and well in Edinburgh. Sir James Young Simpson and Marie Stopes would surely endorse all the recent developments. We strongly encourage you to attend the European Society of Contraception meeting in Edinburgh in June and we look forward to welcoming and meeting many of you then.

Statements on funding and competing interests

Funding. None identified.

Competing interests. None identified.

Ailsa Gebbie, FRCOG, MFFP

Consultant in Community Gynaecology, Lothian Primary Care NHS Trust, Family Planning and Well Woman Service, 18 Dean Terrace, Edinburgh EH4 1NL, UK. E-mail:Ailsa.Gebbie@lpct.scot.nhs.uk

References

1 Stopes M. Married Love. London, UK: A C Fifield, 1918. Reprinted London, UK: Gollancz, 1995.

2 Spark M. The Prime of Miss Jean Brodie. London, UK: Penguin, 1963.

3 Loudon NB, Foxwell M, Potts DM, et al. Acceptability of an ora contraceptive that reduces the frequency of menstruation: the tri-cycle pill regimen. BMJ 1977; 2: 487-490.

4 Glasier A, Gebbie A. Handbook of Family Planning and Reproductive Healthcare (4th edn). London, UK: Churchill Livingstone, 2000.

5 Forrest P. Breast Cancer Screening: Report to the Health Ministers of England, Wales, Scotland and Northern Ireland. London, UK: HMSO, 1986. 